\title{
The European Court of Human Rights' Recourse to External Legal Materials When Interpreting and Applying the Right to Private Life
}

\author{
Alastair Mowbray
}

\section{Introduction}

This chapter considers the European Court of Human Rights' ("the Court") use of external materials when interpreting and applying the right to private life found within Article 8 of the European Convention on Human Rights" ("the Convention" or "the ECHR"). By external materials I mean those sources of human rights norms, principles and standards not found within the ECHR. ${ }^{2}$ For reasons of space and as it has already been discussed elsewhere ${ }^{3}$ I do not intend to specifically examine the Court's application of the European consensus doctrine, whereby the Strasbourg judges have regard to the domestic legal arrangements of the majority of member states when determining if a respondent state has complied with its Convention responsibilities. We shall focus on domestic judgments of nonEuropean courts, international criminal law and different Council of Europe treaties. Regarding other regional human rights courts neither the judgments of the Inter-American Court of Human Rights ${ }^{4}$ nor the African Court on Human and Peoples' Rights ${ }^{5}$ featured in the reasoning of the Court when interpreting private life. However, as we shall analyse below, materials from the United Nations Human Rights Committee were referred to in several Court judgments involving private life.

\section{Scope of the right to respect for private life under Article 8 of the European Convention on Human Rights}

The Court, in both its part-time and full-time forms, has declined to provide a comprehensive definition of the breadth of the right to respect for private life.

"The Court does not consider it possible or necessary to attempt an exhaustive definition of the notion of "private life". However, it would be too restrictive to limit the notion to an "inner circle" in which the individual may live his own personal life as he chooses and to exclude therefrom entirely the outside world not encompassed within

\footnotetext{
${ }^{1}$ Convention for the Protection of Human Rights and Fundamental Freedoms 1950, CETS 005..

${ }^{2}$ For an analysis of the influence of Public International Law materials on the Court's interpretation of a range of ECHR provisions see the Doctoral thesis of my former graduate student Adamantia Rachovitsa,

"Fragmentation or unity of international law revisited: Analysing the ECHR when the Court takes cognisance of public international law norms", (PhD thesis, University of Nottingham, 2012,:

http://etheses.nottingham.ac.uk)

${ }^{3}$ Dzehtsiarou, “Does Consensus Matter? Legitimacy of European Consensus in the Case Law of the European Court of Human Rights" [2011] Public Law 534.

${ }^{4}$ No private life cases are noted in the Research Division's Report, References to the Inter-American Court of Human Rights in the case-law of the European Court of Human Rights", (Strasbourg 2012).

${ }^{5}$ An advanced HUDOC search of "African Court" and Article 8 produced no documents; 5 September 2013.
} 
that circle. Respect for private life must also comprise to a certain degree the right to establish and develop relationships with other human beings."

Therefore, I shall examine a selection of leading cases (all categorised as level one judgments by the Court) dealing with different aspects of private life where the Court has utilised diverse forms of external legal materials as important elements of its reasoning. This will enable us to gain an understanding of, inter alia, the types of materials invoked by the Court and the use being made of those external provisions.

\section{Domestic judgments from non-member States}

From Rees $v U K^{7}$ to Sheffield and Horsham $v U K^{8}$,the Court, by an ever diminishing majority, had found the UK's partial recognition of the new personality of post-operative transsexuals to have met their right to respect for their private lives. However in Christine Goodwin v UK, ${ }^{9}$ a unanimous Grand Chamber found the UK's administrative arrangements no longer satisfied the applicant's right under Article 8.Liberty (a leading UK human rights non-governmental organisation) had submitted a study which disclosed no change in the number of European states giving full legal recognition to transsexuals since its previous third-party submission in Sheffield and Horsham. But the later study cited judgments from New Zealand and Australia where courts had recognised transsexuals' assigned gender for the purpose of validating marriages. The Grand Chamber noted that:

"Already at the time of the Sheffield and Horsham case, there was an emerging consensus within Contracting States in the Council of Europe on providing legal recognition following gender re-assignment ... The latest survey submitted by Liberty in the present case shows a continuing international trend towards legal recognition. In Australia and New Zealand, it appears that the courts are moving away from the biological birth view of sex (as set out in the United Kingdom case of Corbett $v$. Corbett) and taking the view that sex, in the context of a transsexual wishing to marry, should depend on a multitude of factors to be assessed at the time of the marriage."10

The Grand Chamber went on to emphasise that:

"[i]n the twenty first century the right of transsexuals to personal development and to physical and moral security in the full sense enjoyed by others in society cannot be regarded as a matter of controversy requiring the lapse of time to cast clearer light on the issues involved. In short, the unsatisfactory situation in which post-operative

\footnotetext{
${ }^{6}$ Niemietz v Germany, No. 13710/88, Judgment 16 December 1992 at para29.

${ }^{7}$ No. 9532/81, Judgment 17 October 1986.

${ }^{8}$ Nos. 31-31/1997, Judgment 30 July 1998.

${ }^{9}$ No. 28957/95, Judgment 11 July 2002.

${ }^{10}$ Ibidat para 84 .
} 
transsexuals live in an intermediate zone as not quite one gender or the other is no longer sustainable."11

Having regard to the failure of the UK to enhance the legal recognition of post-operative transsexuals since Horsham and Sheffield, the Grand Chamber determined that there had been a violation of the applicant's right to respect for her private life.

In the above case we can see the Court using judgments from non-European states as a basis for supplementing the unchanging extent of the European consensus (and scientific/medical understanding) when reducing the margin of appreciation accorded to a respondent state.

\title{
International Criminal Law
}

A unanimous Chamber took account of this body of law ${ }^{12}$ when elaborating the positive obligations on member states, derived from inter alia Article 8, to undertake effective investigations and bring prosecutions to punish rape (and sexual abuse). The applicant in M.C. $v$ Bulgaria ${ }^{13}$, complained to the police that she had been raped by two men a few days previously (she was just under fifteen years old). Two years later the District Prosecutor terminated the proceeding against the men on the grounds that there was insufficient evidence that the men had used force against the applicant or that she had resisted the men. At Strasbourg the applicant contended that the authorities' failures amounted to a violation of her right to respect for her private life (and a procedural breach of Article 3). Interights(another leading human rights non-governmental organisation)submitted written comments, including analyses of the criminal law applicable to rape in several European countries, a number of states in the USA, Australia, Canada, South Africa and international criminal law (based particularly upon the judgments of the International Criminal Tribunals for Rwanda and the former Yugoslavia).

After noting that the criminal law of numerous states had developed to focus on the lack of consent of the victim as the key element of the offence of rape, the Chamber acknowledged that

\begin{abstract}
"[i]n international criminal law, it has recently been recognised that force is not an element of rape and that taking advantage of coercive circumstances to proceed with sexual acts is also punishable. The International Criminal Tribunal for the former Yugoslavia has found that, in international criminal law, any sexual penetration without the victim's consent constitutes rape and that consent must be given voluntarily, as a result of the person's free will, assessed in the context of the surrounding circumstances. While the above definition was formulated in the particular context of rapes committed against the population in the conditions of an armed conflict, it also reflects a universal trend towards regarding lack of consent as the essential element of rape and sexual abuse." 14
\end{abstract}

\footnotetext{
${ }^{11}$ bbidat para. 90 .

${ }^{12}$ For diverse considerations of this topic see, van den Herik and Stahn (eds.), Future Perspectives on International Criminal Justice, (The Hague:T.M.C. Asser Press/CUP 2010).

${ }^{13}$ No. 39272/98, Judgment 4 December 2003.

${ }^{14}$ Ibidat para 163.
} 
These evolutions in criminal law were a reflection of societies' recognition of each person's sexual autonomy.

"In the light of the above, the Court is persuaded that any rigid approach to the prosecution of sexual offences, such as requiring proof of physical resistance in all circumstances, risks leaving certain types of rape unpunished and thus jeopardising the effective protection of the individual's sexual autonomy. In accordance with contemporary standards and trends in that area, the member States' positive obligations under Articles 3 and 8 of the Convention must be seen as requiring the penalisation and effective prosecution of any non-consensual sexual act, including in the absence of physical resistance by the victim." 15

The Chamber went on to find that the Bulgarian authorities had unduly focused on the issue of whether the applicant had resisted the two men whilst failing to pay sufficient attention to her situation as a vulnerable young person.

"In sum, the Court, without expressing an opinion on the guilt of [the two men], finds that the investigation of the applicant's case and, in particular, the approach taken by the investigator and the prosecutors in the case fell short of the requirements inherent in the States' positive obligations - viewed in the light of the relevant modern standards in comparative and international law - to establish and apply effectively a criminal-law system punishing all forms of rape and sexual abuse."16

Consequently, there had been a breach of the applicant's right to respect for her private life (and Article 3).

So international criminal law was used by the Court as a supplementary source to reinforce the trend in national legal orders towards recognising the absence of consent as the core element of the crime of rape and the consequent ECHR investigation/prosecution duties incumbent upon member states.

\section{European Social Charter}

The (former) European Commission of Human Rights invoked the existence of the European Social Charter ${ }^{17}$ ("the ESC") as a reason for determining that a disability claim fell outside the ambit of Article 8's right to respect for a person's private life in Botta $v$ Italy. ${ }^{18}$ The applicant, who was physically disabled, had complained that he was unable to access/use beaches during a holiday at an Italian seaside town due to the failure of the authorities to ensure the provision of suitable facilities (such as access ramps). Before the Court it was submitted:

"In the Commission's view, the sphere of human relations at issue in the present case concerned a particularly broad range of social relations. The rights asserted by the

\footnotetext{
${ }^{15} \mathrm{Ibid}$. at para 166.

${ }^{16} \mathrm{Ibid}$. at para 185.

17 1961, CETS 35; for commentary, see Harris and Darcy, The European Social Charter 2nd edn (Ardsley, New York: Transnational Publishers, 2001).

18 No 153/96, Judgment, 24 February 1998.
} 
applicant were social in character, concerning as they did participation by disabled people in recreational and leisure activities associated with beaches, the scope of which went beyond the concept of legal obligation inherent in the idea of "respect" for "private life" contained in paragraph 1 of Article 8.

In any event, the social nature of the right concerned required more flexible protection machinery, such as that set up under the European Social Charter. Article 8 was accordingly inapplicable." 19

The respondent government agreed and expressed concern that interpreting Article 8 to encompass an obligation on states to provide suitable recreational facilities for all persons would be "... to transform the Convention institutions into arbiters of the social policies of the States party to the Convention, a role which did not form part of either the object or the purpose of the Convention." 20 However, the applicant contended that his complaint concerned the impairment of his private life and the development of his personality even if there were social and economic aspects of the right being asserted.

The Court, unanimously, determined:]he right asserted by Mr Botta, namely the right to gain access to the beach and the sea at a place distant from his normal place of residence during his holidays, concerns interpersonal relations of such broad and indeterminate scope that there can be no conceivable direct link between the measures the State was urged to take in order to make good the omissions of the private bathing establishments and the applicant's private lifeAccordingly, Article 8 is not applicable." ${ }^{21}$ Hence, the Court did not expressly cite the ESC as a justification for finding the applicant's claim fell outside Article 8, but the judgment is a vivid demonstration that there are boundaries to the Court's protean conception of "private life".

The full-time Court used the ESC as a key component of its reasoning inSidabras and Dziautas $v$ Lithuania $^{22}$, when it held that statutory bans on persons taking up private sector employment concerned the Article 8 private life of those people. The two applicants had worked for the Lithuanian branch of the KGB (Soviet Security Service) prior to 1991. Subsequently, they had been employed as a tax inspector and a public prosecutor in Lithuania. In 1998 the "KGB Act" was passed by the Lithuanian Parliament. The Act provided that former employees of the KGB (and other Soviet security organisations) were prohibited from working for public authorities for ten years commencing from when the Act came into force and listed forms of private sector employment (including banks and communications systems). During 1999 the applicants were dismissed. Before the Court the applicants contended that the statutory ban on them working in those parts of the private sector amounted to a breach of Article 8 alone and together with Article 14. The government submitted, inter alia, that Article 8 did not protect the right to choose a profession or retain a position of employment. Having noted that the Court had previously stated that Article 8 did not guarantee the right to choose a specific profession the Chamber held:

"Nevertheless, having regard in particular to the notions currently prevailing in democratic States, the Court considers that a far-reaching ban on taking up private sector employment does affect "private life". It attaches particular weight in this respect to

\footnotetext{
${ }^{19}$ Ibidat para 28.

${ }^{20}$ Ibidat para 30 .

${ }^{21}$ Ibid at para 35 .

${ }^{22}$ Nos. 55480/00 and 59330/00, Judgment 27 July 2004.
} 
the text of Article $1 \S 2$ of the European Social Charter and the interpretation given by the European Committee of Social Rights...."23

Under Article 1(2) of the ESC states parties undertake "to protect effectively the right of the worker to earn his living in an occupation freely entered upon". Furthermore, the European Committee of Social Rights had found a discriminatory breach of this right in the context of German dismissals of public sector employees who had been active in supporting the work of the security services of the former German Democratic Republic. (footnote the ESC case?)

The majority of the Chamber (five judges) concluded that there had been a breach of the applicants' rights under Article 14 in combination with Article 8 as the KGB Act was a disproportionate measure (defects included the legislation's failure to adequately define the excluded categories of private sector employment and the belated enactment/implementation of the ban). Given this breach the majority decided that it was not necessary to consider the applicants' complaint concerning Article 8 on its own. However, Judges Mularoni and Loucaides issued separate opinions in which they concluded that there had been violations of Article 8.

In Sidabras and Dziautas the Court was according significant influence to the relevant part of the ESC as that provision had already been applied to a comparable scenario by the Charter's expert Committee. The Court's expansive interpretation of Article 8 private life to encompass statutory restrictions on private sector employment ensured a consistent and harmonious approach between the two Council of Europe treaties and their supervisory bodies.

\section{Convention for the Protection of Individuals with regard to Automatic Processing of Personal Data}

Another Council of Europe treaty that has been accorded a powerful impact in the Court's protection of private life is the Convention for the Protection of Individuals with regard to Automatic Processing of Personal Data. ${ }^{24}$ In S. and Marper v UK, ${ }^{25}$ Privacy International (a UK charity with the primary aim of promoting respect for the right to privacy around the world), via a firm of lawyers, drew the Court's attention to key data-protection rules and principles articulated by the Council of Europe and "insisted on their high relevance for the interpretation of the proportionality requirement enshrined in Article 8 of the Convention." 26 When the Grand Chamber came to examine whether the extensive statutory powers of the police in England to retain and use digital DNA profiles and fingerprints of persons held in the Police National Computer system were "necessary in a democratic society", the Court held that:

"The domestic law must afford appropriate safeguards to prevent any such use of personal data as may be inconsistent with the guarantees of ... Article [8] ... The need for such safeguards is all the greater where the protection of personal data undergoing automatic processing is concerned, not least when such data are used for police purposes. The domestic law should notably ensure that [personal] data are relevant and not excessive in relation to the purposes for which they are stored; and preserved in a form which permits identification of the data subjects for no longer than is required for the purpose for which those data are stored (see Article 5 of the Data Protection Convention and the preamble thereto and Principle 7 of

\footnotetext{
${ }^{23}$ Ibidat para 47.

${ }^{24}$ CETS No. 108 (1981).

${ }^{25}$ Nos. 30562/04 and 30566/04, Judgment 4 December 2008.

${ }^{26}$ Ibidat para 57.
} 
Recommendation $\mathrm{R}(87) 15$ of the Committee of Ministers regulating the use of personal data in the police sector). The domestic law must also afford adequate guarantees that retained personal data was efficiently protected from misuse and abuse (see notably Article 7 of the Data Protection Convention). The above considerations are especially valid as regards the protection of special categories of more sensitive data (see Article 6 of the Data Protection Convention) and more particularly of DNA information, which contains the person's genetic make-up of great importance to both the person concerned and his or her family (see Recommendation No. R(92)1 of the Committee of Ministers on the use of analysis of DNA within the framework of the criminal justice system)."27

\section{The unanimous Grand Chamber concluded that Article 8 had been breached because of}

the blanket and indiscriminate nature of the powers of retention of the fingerprints, cellular samples and DNA profiles of persons suspected but not convicted of offences, as applied in the case of the present applicants, fails to strike a fair balance between the competing public and private interests and that the respondent State has overstepped any acceptable margin of appreciation in this regard. Accordingly, the retention at issue constitutes a disproportionate interference with the applicants' right to respect for private life and cannot be regarded as necessary in a democratic society." 28

In this case the Data Convention's provisions were used by the Grand Chamber as central elements in the Court's evaluation of the lawfulness, under Article 8(2), of a state's interference with individuals' right to respect for their private lives.

A later Chamber made reference to the Data Convention when determining if covert state surveillance of a suspect's car journeys, by use of a hidden Global Positioning System (GPS) tracking device, amounted to an interference with his right to respect for his private life. In Uzun v Germany ${ }^{29}$, the Federal Prosecutor General authorised the police to install the hidden GPS device as the applicant was suspect of being involved in terrorism. For three months the device was active and it enabled the police to determine the location of the car and its speed once per minute. At the applicant's trial, data from the device was used, together with other surveillance evidence, to show that he had placed bombs at several locations. Before the Court the respondent state argued that the GPS tracking of the applicant's journeys had not amounted to an infringement of his Article 8 private life. However, the Chamber noted:

"Thus, the Court has considered that the systematic collection and storing of data by security services on particular individuals, even without the use of covert surveillance methods, constituted an interference with these persons' private lives (see Rotaru $v$. Romania [GC], no. 28341/95, §§ 43-44, ECHR 2000-V...). The Court has also referred in this context to the Council of Europe's Convention of 28 January 1981 for the protection of individuals with regard to automatic processing of personal data, which came into force - inter alia for Germany - on 1 October $1985 . . . " 30$

\footnotetext{
${ }^{27}$ Ibidat para 103.

${ }^{28}$ Ibidat para 125.

${ }^{29}$ No. 35623/05, Judgment 2 September 2010.

${ }^{30}$ Ibidat para 46.
} 
Taking account of the authorities' systematic collection of the GPS data on the applicant's journeys and its use in constructing a pattern of his movements the Chamber held:

"In the Court's view, GPS surveillance is by its very nature to be distinguished from other methods of visual or acoustical surveillance which are, as a rule, more susceptible of interfering with a person's right to respect for private life, because they disclose more information on a person's conduct, opinions or feelings. Having regard to the principles established in its case-law, it nevertheless finds the above-mentioned factors sufficient to conclude that the applicant's observation via GPS, in the circumstances, and the processing and use of the data obtained thereby in the manner described above amounted to an interference with his private life as protected by Article $8 \S 1 . " 31$

But, given the (relatively) less intrusive nature of GPS tracking the Chamber adopted a more lenient approach to the application of Article 8(2), compared to the Court's established jurisprudence regarding state interception of telecommunications. Therefore, the unanimous Chamber found no breach of Article 8.

Uzun reveals that the Data Protection Convention has relevance to the determination of the scope of "private life" under Article 8(1), whilst $S$. and Marper disclosed the use of the Data Convention in the Court's evaluation of the proportionality of States' utilisation of privacy data under Article 8(2).

\section{United Nations Human Rights Committee}

The Court's primary use of United Nations Human Rights Committee ${ }^{32}$ (hereinafter "the HRC") materials in regard to private life complaints is the citing of $\mathrm{HRC}$ comments $^{33}$, on states' periodic reports under the International Covenant on Civil and Political Rights ${ }^{34}$, as background information regarding the context of the case being determined at Strasbourg. For example, in De Souza Ribeiro $v$ France ${ }^{35}$, the Brazilian applicant challenged the lawfulness of his deportation from French Guiana. The Chamber declared his complaint admissible under Article 13 combined with Article 8, but went on to conclude (by four votes to three) that there had been no violation of his right to an effective domestic remedy to protect his right to respect for his private and family life. He then successfully petitioned the Grand Chamber to rehear his case. Before the latter body Ribeiro submitted that he had received most of his schooling in French Guiana, though he did not have residency papers, whilst living there with his parents, who had permanent residency cards. When he was 17 he was arrested and charged with possession of cocaine. The Cayenne Youth Court, in French Guiana, convicted him and he was sentenced to two years' probation and placed on a training programme. A few months later he was stopped by the police, at a road check, and found not to have any papers giving him permission to be on French soil. He was arrested and later the same day served with an administrative detention and removal order. At $3.11 \mathrm{pm}$ the next day Ribeiro sent two faxes to the Cayenne Administrative Court seeking

\footnotetext{
${ }^{31}$ Ibidat para 52.

${ }^{32}$ Established by Article 28 of the International Covenant on Civil and Political Rights, (No. 14668, 1966). See McGoldrick, The Human Rights Committee: Its Role in the Development of the ICCPR, (Oxford:OUP 1994).

${ }^{33}$ IbidArticle 40(4).

${ }^{34}$ IbidArticle 40(1).

${ }^{35}$ No. 22689/07, Judgment 18 December 2012.
} 
judicial review and urgent suspension of the deportation order issued against him. At $4 \mathrm{pm}$ he was deported to Brazil. Later that day the Cayenne Administrative Court declared his request for urgent suspension of the deportation order as devoid of purpose given his removal. Some months later the Cayenne Administrative Court upheld his application for judicial review of the deportation order and the authorities in French Guiana have subsequently issued Ribiero with a series of annual residency permits for his private and family life.

In "The Facts" section of the Grand Chamber's De Souza Ribeiro judgment a subsection outlined "Relevant International Instruments and Practice". The third item in the latter category, after Council of Europe and EU provisions, (this sentence does not follow) was an extract from the HRC's 2008 concluding comments on the fourth periodic report of France.

"[N]o recourse to the courts is available to persons deported from the overseas territory of Mayotte, involving some 16,000 adults and 3,000 children per year, nor in French Guiana ...

The State party should ensure that the return of foreign nationals, including asylumseekers, is assessed through a fair process that effectively excludes the real risk that any person will face serious human rights violations upon his return.

Undocumented foreign nationals and asylum-seekers must be properly informed and assured of their rights, including the right to apply for asylum, with access to free legal aid. The State party should also ensure that all individuals subject to deportation orders have an adequate period to prepare an asylum application, with guaranteed access to translators, and a right of appeal with suspensive effect." 36

The Grand Chamber was unanimous in concluding that the applicant had suffered a violation of Article 13 in conjunction with Article 8.

"Next, and above all, the Court is obliged to observe that, after applying to the administrative court on 26 January 2007 at 3.11 p.m., the applicant was deported to Brazil at 4 p.m. the same day. In the Court's view the brevity of that time lapse excludes any possibility that the court seriously examined the circumstances and legal arguments in favour of or against a violation of Article 8 of the Convention in the event of the removal order being enforced.

The result is that at the time of his removal the applications lodged by the applicant and the circumstances concerning his private and family life had not been effectively examined by any national authority. In particular, bearing in mind the chronology of the facts of the present case, the Court cannot but note that no judicial examination was made of the merits of applicant's pleadings or of his urgent application for interim measures." 37

So in the above case the Grand Chamber cited an earlier HRC report which had addressed the same problem as the application before the Court. However, the Grand Chamber did not expressly incorporate the HRC's comments into its determination of a breach of the ECHR.

In the contemporaneous case of El-Masri $v$ The Former Yugoslav Republic of Macedonia, ${ }^{38}$ the Grand Chamber dealt with the ECHR liabilities of a member state that had co-operated with the United States of America's Central Intelligence Agency's "extraordinary

\footnotetext{
${ }^{36}$ Ibidat para 50.

${ }^{37}$ Ibidat para 94.

38 No. 39630/09, Judgment 13 December 2012.
} 
rendition" programme of detentions, inter-continental transportation and unacknowledged imprisonment and interrogation of suspected terrorists. Despite the denials of the respondent government before the Court that it was complicit in the detention and transfer of the applicant German national to USA agents, the Grand Chamber found convincing evidence to support El-Masri's contentions. These included, being held by armed men in a Macedonian hotel for several weeks, his transfer to the custody of USA agents at Skopje airport (whereupon he was subjected to "capture-shock" mal-treatment, which the Grand Chamber found amounted to torture in breach of ECHR, Article 3) followed by his forced transportation to Afghanistan where he was detained (probably in a CIA facility, known as the "Salt Pit", located in a disused brick-works) for four months during which he was repeatedly subjected to brutal interrogations. Eventually, he was flown back to Europe and released in the Albanian countryside.

In "The Facts" section of the Grand Chamber's judgment in El-Masri there was a subsection encompassing "International inquiries relating to the applicant's case". Following extracts from reports produced by the Parliamentary Assembly of the Council of Europe and the European Parliament there was a brief account of the HRC's recommendations concerning the applicant, given as part of the Committee's periodic review of Macedonia's compliance with the ICCPR.

"[T]he State party should consider undertaking a new and comprehensive investigation of the allegations made by Mr Khaled El-Masri. The investigation should take account of all available evidence and seek the cooperation of Mr El-Masri himself ..."39

The Grand Chamber went on to conclude, inter alia, that Macedonia had breached the procedural limb of ECHR Article 3 by failing to conduct an effective investigation into the applicant's complaint that he had been subjected to mal-treatment, violating the substantive prohibitions contained within that Article, for which the respondent state was responsible.

"[T]he Court also wishes to address another aspect of the inadequate character of the investigation in the present case, namely its impact on the right to the truth regarding the relevant circumstances of the case. In this connection it underlines the great importance of the present case not only for the applicant and his family, but also for other victims of similar crimes and the general public, who had the right to know what had happened. The issue of "extraordinary rendition" attracted worldwide attention and triggered inquiries by many international and intergovernmental organisations, including the UN human rights bodies, the Council of Europe and the European Parliament. The latter revealed that some of the States concerned were not interested in seeing the truth come out." 40

Hence, the Grand Chamber made express reference to the UN human rights institutions activities in regard to the USA's extraordinary rendition programme when applying Article 3 to the applicant's complaints. However, when the Grand Chamber examined El-Masri's submission that his ordeal had seriously violated his right to respect for his private and family life guaranteed by Article 8 no mention was made of the HRC's work. Instead, the Grand Chamber noted that its established case-law provided that "private life" embraced circumstances where a person had been deprived of their liberty and treatment which undermined a person's dignity. Given, the Court's earlier findings that Macedonia had breached the applicant's rights under Article 3 and Article 5 (including the respondent state's responsibility under the Convention for El-Masri's detention in Afghanistan by the USA), the

\footnotetext{
${ }^{39}$ Ibidat para 52.

${ }^{40}$ Ibidat para 191. For an overview of the Council of Europe's investigations see, Mowbray, Cases, Materials and Commentary on the ECHR $3^{\text {rd }}$ ed., (Oxford:OUP 2012) pp.257-259.
} 
Grand Chamber held that Macedonia had also violated his right to respect for his private and family life as his treatment was "not in accordance with the law" as required by Article 8(2).

Sometimes applicants have expressly invoked HRC comments to support their claims of breaches of Article 8, for example, $A, B$ and $C v$ Ireland $^{41}$, concerned three women's contention that their inability to obtain lawful abortions in Ireland, on health and well-being grounds, violated their right to respect for their private lives. In "The Facts" section of the Grand Chamber's judgment a sub-section outlined "Relevant European and international material". Within the latter the Court noted that the HRC's concluding comments, issued in 2008, on the third periodic report of Ireland, stated:

"The Committee reiterates its concern regarding the highly restrictive circumstances under which women can lawfully have an abortion in the State party. ... The State party should bring its abortion laws into line with the Covenant." 42

Furthermore, in the applicants' contention to the Grand Chamber that the Irish legal restrictions on lawful abortions were disproportionate to the legitimate aim of protecting foetal life they cited the HRC as support for the view that; "[t]he international human rights standards' consensus also tended to permitting legal abortion to protect the health and wellbeing of a woman ... and to the decriminalising of abortion." ${ }^{43}$ In their joint written third-party submission to the Court, the Centre for Reproductive Rights (a global legal advocacy nongovernmental organisation focussing on reproductive rights) and the International Reproductive and Sexual Health Law Programme (a part of the University of Toronto's Faculty of Law) submitted that the Grand Chamber's consideration of the case should be "informed" by "international human rights' laws and comparative standards". ${ }^{4}$ These organisations claimed that the HRC believed states were required by international law to permit women to have abortions where necessary to protect their health.

The Grand Chamber did not refer to the HRC's comments in its interpretation and application of Article 8. Instead, the Court focused on its own earlier jurisprudence and doctrines. Confirming its established broad approach to the scope of private life, including the right to personal autonomy and development, the Grand Chamber also accepted that a pregnant woman's right to respect for her private life should be assessed against countervailing interests, such as those of the unborn child.

"While Article 8 cannot, accordingly, be interpreted as conferring a right to abortion, the Court finds that the prohibition in Ireland of abortion where sought for reasons of health and/or well-being about which the first and second applicants complained, and the third applicant's alleged inability to establish her qualification for a lawful abortion in Ireland, come within the scope of their right to respect for their private lives and accordingly Article 8." 45

Relying on the margin of appreciation doctrine a large majority of the Grand Chamber, 11 votes to 6 , concluded that because of the strong moral opposition to abortion in Ireland there had been no violation of Article 8 regarding applicants $A$ and $B$.

"Accordingly, having regard to the right to lawfully travel abroad for an abortion with access to appropriate information and medical care in Ireland, the Court does not

\footnotetext{
${ }^{41}$ No. 25579/05, Judgment 16 December 2010.

${ }^{42}$ Ibid. at para 111.

${ }^{43}$ Ibid. at para 172.

${ }^{44}$ Ibid. at para 208.

${ }^{45}$ Ibid. at para 214.
} 
consider that the prohibition in Ireland of abortion for health and well-being reasons, based as it is on the profound moral views of the Irish people as to the nature of life and as to the consequent protection to be accorded to the right to life of the unborn, exceeds the margin of appreciation accorded in that respect to the Irish State. In such circumstances, the Court finds that the impugned prohibition in Ireland struck a fair balance between the right of the first and second applicants to respect for their private lives and the rights invoked on behalf of the unborn." 46

Whilst the dissentients vigorously disagreed with the reasoning of the majority regarding the breadth of the margin of appreciation to be accorded to Ireland. ${ }^{47}$ They believed that a European consensus existed amongst a significant majority of member states to permit lawful abortions on health and well-being grounds that were not accepted in Ireland. Therefore, according to the Court's normal approach the width of the margin of appreciation accorded to Ireland should have been correspondingly reduced. But the majority had given preference to the moral beliefs asserted by the respondent state:

"[l]t is the first time that the Court has disregarded the existence of a European consensus on the basis of "profound moral views". Even assuming that these profound moral views are still well embedded in the conscience of the majority of Irish people, to consider that this can override the European consensus, which tends in a completely different direction, is a real and dangerous new departure in the Court's case-law."48

All the judges were in agreement that there had been a breach of the third applicant's right to respect for her private life due to the failure of the Irish authorities to provide her with an effective procedure by which she could have established whether she was entitled to an abortion on medical grounds.

The judgment in $A, B$ and $C$ may be considered to demonstrate that even when parties to a Strasbourg proceeding expressly invoke HRC views the Court will concentrate upon its own doctrines when interpreting and applying the right to private life. Despite the diametrically opposite analyses of the Court's margin of appreciation doctrine by the majority and the minority, neither group made reference to the HRC's comments on Ireland's restrictive abortion law. Instead the judges took account of their own perspectives on the European consensus and the significance of Irish moral beliefs regarding abortion.

Very interestingly, failings in a state's administration of its abortion legislation disclosed during the ICCPR reporting process were expressly integrated into the Court's judgment finding a breach of Article 8 in the earlier case of Tysiac $v$ Poland ${ }^{49}$. The applicant contended that the refusal of the authorities to provide her with an abortion, necessary because of her medical condition, had violated her right to respect of her private life. In the Court's elaboration of "The Facts" of the case it included a section on "Relevant Non-Convention Material" which contained extracts from the HRC's monitoring of Poland's abortion law and practice. The Court noted that in 1999 the HRC had expressed its concern about Poland's "strict laws on abortion". ${ }^{50}$ The next Polish periodic report acknowledged that "the Law's provisions are not fully implemented and that some women, in spite of meeting the criteria

\footnotetext{
${ }^{46}$ Ibid. at para 241.

47 Joint Partly Dissenting Opinion of Judges Rozakis, Tulkens, Fura, Hirvelä, Malinverni and Poalelungi.

${ }^{48}$ Ibid. at para 9.

49 No. 5410/103, Judgment 20 March 2007.

${ }^{50}$ Ibid. at para 48.
} 
for an abortion, are not subject to it." 51 The HRC, in its subsequent 2004 concluding observations, reiterated:"deep concern about restrictive abortion laws in Poland, which may incite women to seek unsafe, illegal abortions, with attendant risks to their life and health. It is also concerned at the unavailability of abortion in practice even when the law permits it, for example in cases of pregnancy resulting from rape, and by the lack of information on the use of the conscientious objection clause by medical practitioners who refuse to carry out legal abortions." 52 When the Court examined if Poland had complied with its positive obligations to respect the applicant's right to respect for her private life the judgment observed that "....in its fifth periodic report to the ICCPR Committee, the Polish government acknowledged, inter alia, that there had been deficiencies in the manner in which the 1993 Act had been applied in practice. This further highlights, in the Court's view, the importance of procedural safeguards regarding access to a therapeutic abortion as guaranteed by the 1993 Act." 53

The majority, of six judges, went on to find a breach of Article 8 because, inter alia,

"[t]he Court concludes that it has not been demonstrated that Polish law as applied to the applicant's case contained any effective mechanisms capable of determining whether the conditions for obtaining a lawful abortion had been met in her case. It created for the applicant a situation of prolonged uncertainty. As a result, the applicant suffered severe distress and anguish when contemplating the possible negative consequences of her pregnancy and upcoming delivery for her health." ${ }^{24}$

So the admission by the respondent state, during the ICCPR reporting process, of defects in the implementation of national abortion legislation was a factor in the Court's focus on the domestic remedies available to the applicant when she had unsuccessfully sought an abortion on medical grounds. This concentration on the procedural aspects of the applicant's claim also enabled the Court to avoid ruling on the much more controversial issue of whether a woman could claim a right to an abortion via Article 8.

More rarely the Court has noted pertinent HRC case-law. In El-Masri, ${ }^{55}$ "The Facts" contained a sub-section "Relevant case-law of foreign jurisdictions and international bodies", after extracts from Courts of Appeal judgments in England and the USA there was a summary of the HRC's findings in Alzery $v$ Sweden ${ }^{56}$. The latter complaint involved an Egyptian who had been refused asylum in Sweden and subsequently deported via American agents who had subjected Alzery to similar rendition mal-treatment as El-Masri. The HRC concluded that Sweden had violated Article 7 of the ICCPR (prohibition of torture or cruel, inhuman or degrading treatment/punishment) by, inter alia, permitting the American agents' maltreatment when he was handed over to them at a Swedish airport. However, the legal reasoning element of the Grand Chamber's judgment in El-Masri did not mention Alzery.

\footnotetext{
${ }^{51}$ Ibid. at para 49.

${ }^{52}$ Ibid. at para 50.

${ }^{53}$ Ibid. at para 115.

${ }^{54}$ Ibid. at para 124.

${ }^{55}$ Supra n 38.
}

${ }^{56}$ CCPR/C/88/D/1416/2005 (2006). 
A few months earlier a differently composed Grand Chamber ${ }^{57}$ not only referred to a HRC complaint in "The Facts" section of its judgment but also cited the UN case-law in its reasoning under "The Law". That occurred in the highly significant case of Nada $v$ Switzerland, ${ }^{58}$ where the Strasbourg Court ruled on the liability of a member state under the ECHR in regard to the latter's implementation of United Nations Security Council's antiterrorism sanctions. ${ }^{59}$ The applicant was a dual Italian and Egyptian national who, since 1970, had his home in a tiny Italian enclave surrounded by Swiss territory. Following bombings during 1999, in East Africa by Osama bin Laden's associates, the Security Council, adopted a series of Resolutions that introduced sanctions against listed organisations and persons connected with bin Laden and al-Qaeda. The Resolutions obliged states to seize the financial assets of listed organisations and persons, together with denying them entry or transit through national territories. Switzerland began implementing these sanctions in 2000 , even though it did not formally join the UN for two more years. In October 2001 the Swiss Federal Prosecutor started an investigation into Nada. A few weeks later theUSA government added his name to the Security Council sanctions list. During 2003 Nada's special border-crossing permit that enabled him to transit across Swiss territory to and from his Italian home was revoked by the Swiss authorities. In May 2005 the Swiss Federal Prosecutor ended the investigation into Nada, finding the accusations against him were unsubstantiated. Nada subsequently requested the Swiss federal government to delete his name from the national Ordinance that implemented the UN sanctions, but that was refused as the government asserted only the UN could amend the list of designated persons/organisations. In 2007 the Security Council rejected Nada's request to be delisted. The Italian government requested the Sanctions Committee to delist Nada, in July 2008, but that request was denied. In July 2009 the USA requested Nada's delisting by the Sanctions Committee. The following month he made a similar request and in September 2009 Switzerland notified the Sanctions Committee that the Federal Prosecutor had found no evidence linking Nada with other persons or organisations on the list. On 23 September 2009 Nada's name was removed from the Security Council's sanctions list and in early October 2009 the Swiss Ordinance was amended accordingly.

Before the Grand Chamber Nada alleged that, inter alia, the Swiss restrictions imposed on his travel and the addition of his name to the list annexed to the Swiss sanctions Ordinance violated his right to respect for his private and family life by preventing him from participating in family gatherings and by damaging his honour and reputation. In "The Facts" the Grand Chamber identified two sets of "Relevant international case-law", firstly litigation before the (then) Court of Justice of the European Communities ${ }^{60}$ and secondly the HRC case of Sayadi and Vinck $v$ Belgium ${ }^{61}$. The latter concerned two Belgian nationals who had been placed on the UN sanctions list after their home state had provided information concerning a criminal investigation into their activities. Sayadi and Vinck were then subject to

\footnotetext{
${ }^{57}$ Only six judges sat in both Grand Chamber formations determining El-Masri and Nada.

${ }^{58}$ No. 10593/08, Judgment 12 September 2012.

${ }^{59}$ For an argument that the Court should adopt a cautious approach to indirectly reviewing the actions of the Security Council see, Tomuschat, "The European Court of Human Rights and the United Nations" in Follesdal, Peters and Ulfstein (eds), Constituting Europe: The European Court of Human Rights in a National, European and Global Context (Cambridge: CUP 2013).
}

\footnotetext{
${ }^{60}$ Yassin Abdullah Kadi and Al Barakaat International Foundation v Council and Commission, C-402/05 P and C415/05 P, 3 September 2008, where EC Regulations implementing the same Security Council sanctions system were found to breach EC fundamental rights.
}

${ }^{61}$ No. 1472/2006, Judgment 22 October 2008. 
travel bans and their names were not removed from the UN sanctions list until 2005 (after a Belgian court had ordered the government to seek their delisting by the Security Council). The HRC found violations of Article 12 (freedom of movement) and Article 17 (protection of honour and reputation) of the ICCPR.

When the Grand Chamber examined the proportionality of the Swiss measures imposed on the applicant it commented:

"...the Court is surprised by the allegation that the Swiss authorities did not inform the Sanctions Committee until 2 September 2009 of the conclusions of investigations closed on 31 May 2005. Observing, however, that the veracity of this allegation has not been disputed by the Government, and without any explanation having been given by the latter for such delay, the Court finds that a more prompt communication of the investigative authorities' conclusions might have led to the deletion of the applicant's name from the United Nations list at an earlier stage, thereby considerably reducing the period of time in which he was subjected to the restrictions of his rights under Article 8 (see, in this connection, Sayadi and Vinck (Human Rights Committee)..."62

Furthermore, the Grand Chamber was also critical of Switzerland's passive stance towards efforts to have Nada's name removed from the UN sanctions list.

"It has been established that the applicant's name was added to the United Nations list, not on the initiative of Switzerland but on that of the United States of America. Neither has it been disputed that, at least until the adoption of Resolution 1730 (2006), it was for the State of citizenship or residence of the person concerned to approach the Sanctions Committee for the purposes of the delisting procedure. To be sure, in the applicant's case Switzerland was neither his State of citizenship nor his State of residence, and the Swiss authorities were not therefore competent to undertake such action. However, it does not appear that Switzerland ever sought to encourage Italy to undertake such action or to offer it assistance for that purpose (see, mutatis mutandis, the case of Sayadi and Vinck (Human Rights Committee)."

Therefore, the Grand Chamber went on to conclude, unanimously, that the lengthy restrictions imposed on the applicant's freedom of movement by the Swiss authorities had violated his right to respect for his private and family life by being disproportionate to the legitimate aims of preventing crime and protecting national security. So, in Nada HRC caselaw regarding an analogous complaint was utilised by the Grand Chamber as a component of its proportionality assessment.

A more divisive issue for the Grand Chamber involved Nada's allegation that the Swiss addition of his name to their national list of persons/organisations subject to UN sanctions also constituted a breach of Article 8 by impugning his honour and reputation. The Grand Chamber declined to rule on the reputation complaint simply stating that as it had found a breach of Article 8 (discussed above) "it does not need to examine that complaint separately". ${ }^{64}$ But Judge Rozakis, joined by Judges Spielmann and Berro-Lefevre, issued a Concurring Opinion in which they disagreed with the way the Court had dealt with the reputational element of Nada's complaint under Article 8. They considered the Court had wrongly "side-stepped" the reputational complaint.

"The applicant's complaint concerning his honour and reputation is not a distinct complaint which is independent from all the other aspects of his allegation of a violation of Article 8 of the Convention. It is one of the constitutive parts of his main complaint that his private and family life were affected by the Swiss authorities' conduct. It is well known - and undoubtedly the applicant was relying on this - that honour and reputation have been considered by the Court as an element of private life

\footnotetext{
${ }^{62}$ Supra n 58at para 188.

${ }^{63}$ Ibid. at para 194

${ }^{64}$ Ibid. at para 199.
} 
worthyof particular protection under Article 8. By discarding this particular aspect of an otherwise homogeneous and comprehensive complaint, the Court has given the wrong impression that honour and reputation should be examined separately - if at all - and that they do not necessarily belong to the hard core of the constitutive parts of private life." 65

Despite the fact that the HRC's finding that the placing of Sayadi and Vinck's names on the UN sanctions list, together with associated publicity, constituted a violation of their right to protection of their honour and reputation under the ICCPR, neither the Court nor Judge Rozakis and his two fellow judges made reference to that case-law when dealing with Nada's similar complaint under Article 8.

Overall, we have seen that a number of extracts from the HRC's reporting process and case-law have been included in the Court's private life judgments. However, the majority of these HRC materials have been confined to the "The Facts" section of judgments and they were not discussed in the Court's reasoning elaborated in "The Law" component of the judgments. Rare examples of HRC materials being expressly referred to in the Court's application of the right to respect for private life were the respondent state's acknowledgement of failings in its administration of relevant domestic law during the ICCPR periodic reporting process (Tysiac) and comparable HRC case-law when the Court was assessing the proportionality of the respondent state's interference with the applicant's private life (Nada). The above Court judgments do not disclose the HRC materials having any significant influence on how the Court interpreted the scope of private life.

\section{Conclusions}

The above case-law has disclosed that a broad range of external legal materials have been utilised by the Court in its interpretation and application of the right to respect for private life. These have included; non-European domestic jurisprudence, international criminal law, other Council of Europe treaties and HRC reports and case-law. Furthermore, the Court's use of these external materials has been diverse. They have encompassed; supplementing and re-enforcing developments in the member states' domestic legal orders as a basis for the Court elaborating positive obligations upon these states to respect applicants' right to respect for their private lives (Christine Goodwin, M.C.) and ensuring a consistent Council of Europe response between different treaty bodies (Sidabras and Dziautas). External materials have also been incorporated in the Court's reasoning when defining the scope (Uzun) and limitations ( $S$. and Marper, Nada) of the protection of private life under Article 8. However, generally, the Court did not use external materials as the definitive element in its interpretation and application of private life. The Council of Europe's treaties on social rights and data protection were the most powerful external sources that we encountered. As they were products of the same international organisation that created the ECHR system it is not surprising that the Court accorded them such weight where their provisions overlapped with the Convention.

It is noteworthy that NGO's, via third-party interventions in Strasbourg litigation, have drawn the Court's attention to different types of external legal materials in several of the above cases: Liberty in Christine Goodwin, Interights in M.C., Privacy International in S. and Marper and the Centre for Reproductive Rights/the International Reproductive and Sexual Health Law Programme in $A, B$ and $C$. We may speculate that the international/global focus of many of these human rights orientated NGOs enables them to bring a wider view of

\footnotetext{
${ }^{65} \mathrm{Ibid}$. at Concurring Opinion of Judge Rozakis Joined by Judges Spielmann and Berro-Lefevre.
} 
relevant legal materials to the attention of the Court, which has the potential to help crosspollinate the Court's jurisprudence with legal developments beyond the Convention. ${ }^{66}$

A new evolution in Strasbourg proceedings occurred in September 2013 when the Council of Europe's Commissioner for Human Rights made his first oral intervention in a case before the Court. ${ }^{67}$ Nils Muiznieks supported his predecessor's earlier written comments $^{68}$ in a case brought by an NGO on behalf of a deceased eighteen year old, who had profound learning disabilities and was HIV positive. ${ }^{69}$ The Commissioner, inter alia, contended that the ECHR should be interpreted so as to enable NGOs to make applications on behalf of persons with disabilities. He based his argument on a number of grounds including the principle of effectiveness and the case-law of other international courts including the Inter-American Court of Human Rights. The Grand Chamber implicitly followed the Commissioner's proposition that in cases such as this, involving "exceptional circumstances", an NGO could represent a vulnerable victim who had been unable to give his/her formal authorisation for representation,${ }^{70}$ So there is now another mechanism which enables the introduction of submissions based upon external legal mechanisms into litigation before the Court. However, given the limited resort to this power by Commissioners since 2010, we should not expect its frequent exercise.

\footnotetext{
${ }^{66}$ For a study of the general interactions between NGOs and the Court see, Cichowski, "Civil Society and the European Court of Human Rights" in Christofferson and Madsen (eds), The European Court of Human Rights between Law and Politics (Oxford: OUP 2011).

${ }^{67}$ Protocol 14 amended Article 36 of the ECHR, from June 2010, to enable the Commissioner to submit written comments and participate in all hearings before Chambers and the Grand Chamber.

${ }^{68}$ CommDH(2011)37, Strasbourg 14 October 2011.

${ }^{69}$ The Centre for Legal Resources on behalf of Valentin Campeanu v Romania, (No. 47848/08), Grand Chamber hearing 4 September 2013.

70 No. 47848/08, Judgment of 17 July 2014 at para. 112.
} 